\title{
Transformational Leadership, High Performance Work Practices, and an Effective
}

\section{Organization}

\begin{abstract}
Although transformational leadership is touted as an important approach for improving employee well-being and an effective organization, very little is known about how its key principles can be manifested through specific Human Resource Management (HRM) systems. This is unsatisfactory as leadership is pertinent to the management of human resources and many HRM researchers and practitioners would benefit from a theoretical understanding of how effective leadership principles can be strengthened by HRM systems. This review paper discusses the ways in which transformational leadership can be applied in tandem with a particular type of HRM system, High Performance Work Practices (HPWP). The paper explores the role of HPWP as a mechanism for accentuating the transformational leader's positive impact on employee well-being and organizational performance. The contribution of this paper is to link a contemporary leadership theory to HRM and generate insights that will lead to empirical research.
\end{abstract}

\section{Keywords:}

Transformational leadership, high performance work practices, employee well-being, organizational performance 


\section{Transformational Leadership, High Performance Work Practices, and an Effective}

\section{Organization}

In recent years, the research on what makes an effective organization has dominated much of the empirical and scientific literature. Central to this research is the role of employee well-being in promoting sustainable competitive success for an organization. Employee wellbeing in this context refers to the overall quality of employees' mental, psychological, and emotional functioning at work (Danna \& Griffin, 1999). Within organizational studies, transformational leadership is identified as a model for improving employee well-being and performance (Skakon, Nielsen, Borg \& Guzman, 2010; Judge \& Piccolo, 2004; Tims, Bakker \& Xanthopoulou, 2011; García-Morales, Jiménez-Barrionuevo \& Gutiérrez-Gutiérrez, 2012). Transformational leadership involves articulating a vision that elevates individuals to higher levels of motivation, and inspiring them to buy into and deliver this vision. One major theoretical gap in the literature, however, concerns the lack of integration between transformational leadership and Human Resource Management (HRM) systems within an organization (Ogbonnaya, Daniels, Connolly, van Veldhoven, and Nielsen, 2015; et al., 2015; Zhu, Chew \& Spangler, 2005). Little attention has been paid to an understanding of how transformational leadership and HRM systems may work together in promoting employee well-being and organizational effectiveness. This is unsatisfactory as leadership is imperative to the management of human resources (Piccolo \& Colquitt, 2006), and many HRM researchers and practitioners would benefit from theoretical insights as to how effective leadership principles can be reinforced by HRM systems.

The present paper attempts to fill this theoretical gap through its review of recent and erstwhile research on transformational leadership and HRM systems. Specifically, the paper illustrates how transformational leadership may be used in tandem with a specific type of HRM system, High Performance Work Practices (HPWP), for the benefit of an organization. 
HPWP are a system of unique but interdependent HRM practices aimed at optimizing employees’ skills, knowledge and abilities for organizational effectiveness (Beltrán-Martín, Roca-Puig, Escrig-Tena \& Bou-Llusar, 2008). They typically include team-based working, information sharing, selective hiring, training, contingent pay, performance appraisals, and job autonomy (Appelbaum, Bailey, Berg \& Kalleberg, 2000; Combs, Liu, Hall \& Ketchen, 2006). Since its introduction in the mid-1990s, the HPWP framework has gained prominence as an innovative strategy for shaping positive employee attitudes and developing a more effective organization. HPWP are associated positively with employee well-being and organizational performance outcomes (Van De Voorde, Paauwe \& Van Veldhoven, 2012).

The present review proposes that HPWP may serve as a medium through which the basic elements of transformational leadership - idealized influence, inspirational motivation, intellectual stimulation, and individualized consideration (Bass, 1991; Barroso Castro, Villegas Perinan \& Casillas Bueno, 2008) - can be made observable in the workplace. Once the vision and strategic objectives are established by the transformational leader, alignment with HPWP may provide a blueprint for employees to buy into the vision and become passionate about it (Ogbonnaya et al., 2015). This assumption is premised on plausible overlap between the characteristics of transformational leadership and key components of HPWP. For example, a transformational leader could intellectually stimulate employees by emphasizing job autonomy in the design of employees' jobs (Piccolo \& Colquitt, 2006). The leader could manifest individualized consideration through training and performance appraisals (Zhu et al., 2005), or demonstrate his/her role as an inspirational motivator through effective information sharing activities. Thus, the present paper contributes to the literature by portraying HPWP as a vehicle for conveying the benefits of transformational leadership. The paper aims to give new insights into existing concepts in transformational leadership and HPWP, and stimulate fresh ideas that will lead to empirical research. 
We begin this paper by describing the concepts of transformational leadership and HPWP, with emphasis on their main characteristics and effects on employee and organizational outcomes. We examine how transformational leadership and HPWP may be used together for the benefit of the organization, and attempt to map key elements of transformational leadership onto individual components of HPWP. We finish our review by exploring circumstances under which the basic principles of transformational leadership and HPWP may be misapplied.

\section{Transformational leadership}

The concept of transformational leadership is credited to James MacGregor Burns, a political scientist who described transformational leadership as occurring when a leader focuses on elevating followers to higher levels of morality and motivation (Burns, 1978: 20). The transformational leader is seen as a leader who broadens the interests of followers through a process of mutual stimulation, and appeals to them on a more emotional level. $\mathrm{He} / \mathrm{she}$ is able to articulate an attractive vision and support followers to go beyond their self interests in achieving this vision (Bass, 1991; Bass \& Riggio, 2006; Ogbonnaya et al., 2015). The leader also shapes positive follower behaviours through being a charismatic role-model, encouraging creativity among followers, and paying close attention to the individual needs of followers (Avolio \& Bass, 1995). Transformational leadership may be conceptualized at the workplace level in terms of a high-ranking person (e.g., a CEO) who oversees organizational policies and operations (see Zhu et al., 2005), or a person (e.g., a line manager) with operational responsibility for running and managing key organizational activities (see Nielsen, Randall, Yarker \& Brenner, 2008). The present paper conceptualizes transformational leadership at the workplace level, but considers the leader as one who is directly responsible for employees. 
Transformational leadership is characterized by four main dimensions (Bass, 1991; Bass \& Riggio, 2006; Van Knippenberg \& Sitkin, 2013; Nielsen et al., 2008). The first, 'idealized influence' connotes the leader's ability to act as a role model. This behaviour enables the leader to act ethically and share risks with subordinates, so that the leader is admired, respected, and trusted by followers (Bass \& Riggio, 2006). Idealized influence may be further distinguished as behavioural idealized influence, the leader's ability to surpass his/her own personal interests for the collective good of the group, and attributed idealized influence, followers' willingness to emulate the leader's personality and show loyalty towards the leader due to the leader's admirable qualities (Barroso Castro et al., 2008). Another dimension of transformational leadership is 'inspirational motivation'. This reflects a leader's ability to formulate an attractive vision, communicate this vision in a precise and consistent manner, and set optimistic but realistic expectations for followers to achieve the vision (Bass, 1991). A leader who exhibits inspirational motivation is also a leader who communicates high optimism about future goals and expectations, and does not enshroud vital information from followers.

The third dimension of transformational leadership is 'intellectual stimulation', which connotes the leader's ability arouse innovative thinking and inspire followers to adopt new ways of looking at old problems. A leader who intellectually stimulates his/her followers encourages them to challenge preconceived ideologies and take reasonable risks when necessary to achieve set objectives. The fourth dimension of transformational leadership is ‘individualized consideration'. This behaviour connotes a leader's ability to recognize differing personalities among the followers, coach or mentor them, pay particular attention to followers' special needs, and provide new learning opportunities for followers to develop both professionally and personally. Transformational leaders who are individually 
considerate are also able to connect with their subordinates at an interpersonal or emotional level.

Previous studies have tended to associate transformational leadership with employees' job satisfaction (Barroso Castro et al., 2008), work engagement (Tims, Bakker \& Xanthopoulou, 2011) and psychological well-being (Nielsen et al., 2008). The commonality among these studies lies in the transformational leader's capacity to promote employees' experience of meaningfulness and purpose. Using a longitudinal study design, Nielsen et al. (2008) showed that managers' perceived transformational leadership style correlates positively with the degree to which employees reported being happy, vivacious and energetic. Nielsen et al. argued that employees whose managers engaged in transformational leadership behaviours tended to experience role clarity, work meaningfulness, and opportunities for development, and these led to increases in employees' psychological well-being. Also, Tims et al. (2011) argued that employees are more likely to report greater levels of efficacy, dedication, and vigour when exposed to transformational leadership. As noted by Tims et al., the transformational style of leadership enhances employees' day-to-day experience of selfefficacy and this, in turn, might explain employees' daily experience of work engagement.

Research has also documented positive relationships between transformational leadership and organizational performance outcomes such as competitive advantage (Zhu et al., 2005; García-Morales et al., 2012), reduced staff absence rates (Zhu et al., 2005) and improved company sales (Loshali \& Krishnan, 2013). Because transformational leadership inspires employees to perform their jobs at high standards, and provides the right incentives for them to do so, it also creates a set of high-performing employees who are both willing and able to put forth discretionary effort. Such discretionary effort serves to improve the organization's competitiveness in a challenging business environment. García-Morales et al. (2012), in their study of 168 Spanish firms, showed that transformational leadership promotes 
organizational performance through opportunities for knowledge sharing and skills development. Transformational leadership fuels the process of organizational learning, which in turn is essential for survival in today's competitive and changing business environment.

\section{High performance work practices (HPWP)}

The HRM function has gradually evolved from traditional forms of work, characterized by low levels of employee involvement, to a more participative process of support and opportunities for employee skills enhancement (Lengnick-Hall, Lengnick-Hall, Andrade \& Drake, 2009). This evolution has triggered interests in HRM systems such as HPWP as a means to maximizing an organization's potential for competitive success. HPWP are a set of separate but interconnected HRM practices that improve employees' skills and reinforce their level of commitment to organizational goals and values (White et al., 2003; Whitener, 2001; Macky \& Boxall, 2007; Jiang \& Liu, 2015). HPWP enhance employees' commitment by empowering employees to directly influence their jobs, participate in workplace decision-making, and exert themselves on behalf of the organization. This type of empowerment can lead to higher levels of work motivation and meaningfulness, job quality, and overall organizational effectiveness. HPWP are variously referred to as high-involvement work systems (Edwards \& Wright, 2001), high-commitment management practices (Whitener, 2001), workplace innovations (Kalmi \& Kauhanen, 2008).

Although researchers have not reached a consensus as to what practices should be included in HPWP, many studies have described HPWP in terms of the ability-motivationopportunity (AMO) model of HRM (Appelbaum, Bailey, Berg \& Kalleberg, 2000; Jiang, Lepak \& Baer, 2012). The AMO model defines HRM systems by three functional areas: ability-, motivation- and opportunity-enhancing practices. Accordingly, HRM systems that optimize employee well-being and organizational performance tend to do so by enhancing employees' abilities, improving employees' motivation to perform well, and offering 
opportunities for employees to exercise discretionary effort. A key tenet of the AMO model is that all three functional areas are mutually reinforcing and should be represented within HRM systems (Appelbaum et al., 2000). In Table 1, we outline the typical components of HPWP and match them to the AMO functional areas. Our list is by no means exhaustive, but illustrates the set of practices for which some consensus has been reached.

Insert Table 1 about here.

Ability-enhancing practices such as training, induction programs, on-the-job coaching, and selective hiring, serve to improve employees' skills, knowledge and expertise at work (Barling et al., 2003; Jiang et al., 2012). These practices serve to shape employees' compatibility with the job, as well as their adaptability to the work environment. Abilityenhancing practices are also useful for creating a large pool of highly skilled employees with specialist workplace expertise (Gong, Law, Chang \& Xin, 2009). Motivation-enhancing practices influence employees' work motivation, increase their willingness to exercise greater ownership over their jobs, and encourage them to make optimal use of their skills. Such practices include pay schemes, job security guarantees, workplace support, promotion and career-enhancement opportunities (Applebaum et al., 2000; Beltrán-Martín et al., 2008; Macky \& Boxall, 2007). Opportunity-enhancing practices such as participative decisionmaking, team working, task autonomy, performance appraisals and information sharing provide opportunities for active employee involvement in the workplace (Huselid, 1995; Wood, Van Veldhoven, Croon \& De Menezes, 2012). These practices allow employees to apply their creative knowledge in addressing work-related issues more efficiently, rather than being narrowly constrained in their jobs (Kalmi \& Kauhanen, 2008; Combs et al., 2006).

The widely held assumption among researchers is that individual HRM practices are mutually supportive of one another (MacDuffie, 1995; Ichniowski, Shaw \& Prennushi, 1997; 
Jiang \& Liu, 2015); thus, the ability-, motivation- and opportunity-enhancing practices in HPWP should be analysed in coherent bundles, rather than in isolation, to achieve optimal effects. This assumption is consistent with Delery's (1998: 291) notion of "horizontal fit", the idea that HRM practices blend better together when combined into a coherent system. Individual HRM practices tend to have limited capacity to influence workplace outcomes when examined alone, but if used together, their combined effects may be greater than the sum of their individual impact (Ichniowski et al. 1997). HPWP have been associated with employees' job satisfaction (Barling et al., 2003), affective commitment (Gong et al., 2009) and organizational citizenship behaviours (Sun et al., 2007). Organizations adopting HPWP are also likely to achieve labour productivity (Wood et al., 2012), customer service effectiveness (Beltrán-Martín et al., 2008) and financial performance (Huselid, 1995).

\section{Transformational leadership and HPWP}

The literatures on transformational leadership and HPWP have independently shed light on ways to improve employee well-being and organizational performance. Transformational leadership, for example, promotes positive outcomes through four main behaviours - idealized influence, inspirational motivation, intellectual stimulation and individualized consideration. HPWP, on the other hand, foster employees' sense of work empowerment through a coherent set of ability-, motivation-, and opportunity-enhancing HRM practices. Despite the practical and theoretical appeal of these two strands of literature, little attention has been paid to how transformational leadership and HPWP may work together in developing a more effective organization (Ogbonnaya et al., 2015). This is unfortunate as effective leadership is concomitant to the HRM function (Zhu et al., 2005), or at least, the latter could serve as an enabling mechanism for institutionalizing a leader's vision, and making it more sustainable over time (Purcell \& Hutchinson, 2007). HRM 
scholars and practitioners would benefit from theoretical insights into how the principles of transformational leadership can be applied in tandem with HPWP.

We begin our discussion by reiterating that transformational leadership involves articulating an attractive vision and inspiring followers to buy into and deliver this vision. To achieve this, the leader needs to communicate this vision in such a manner as to realize desired outcomes. The HRM characteristics of an organization are particularly useful in this communication process (Zhu et al., 2005; Piccolo \& Colquitt, 2006). HRM systems can provide a platform through which the transformational leader's plan or strategy is conveyed consistently to organizational members. The rationale is that HRM policies, routines, or procedures send strong signals regarding what the organization expects of employees, and what employees can expect from the organization in return (Pereira \& Gomes, 2012; Ogbonnaya et al., 2015). For example, a leader who desires to intellectually stimulate employees may do so by emphasizing job autonomy, task variety, and other discretionary workplace activities in the design of employees' jobs. These activities will help to implicitly communicate the leader's desire and enable employees to make sense of what the leader expects in return.

In one of few studies to examine the signalling effects of HRM practices in the context of transformational leadership, Zhu et al. (2005) noted that a transformational leader's vision can be made more visible if mutually aligned with human-capital-enhancing HRM practices. Zhu et al.'s set of human-capital-enhancing HRM practices was measured by four workplace activities - performance appraisal, recruitment, staff training and compensation systems. Zhu et al. argued that these practices have a significant mediating role in terms of the links between CEO transformational leadership and organizational performance. Similarly, Piccolo and Colquitt (2006) tested and found that the relationships between transformational leadership and positive employee outcomes (e.g., intrinsic 
motivation, goal commitment, and organizational citizenship behaviour) were mediated by employees' perceptions of core job characteristics such as skill variety, task identity, task significance, job autonomy, and feedback on the job. Drawing on evidence from these two studies, and considering that HPWP entail a much wider range of HRM practices, we propose that HPWP provide "higher visibility for HRM practices" (Bowen and Ostroff, 2004: 208) and could therefore serve as a functional platform for translating the outcomes of transformational leadership. Once the transformational leader has articulated a clear and convincing vision, the broad spectrum of HRM practices associated with HPWP will enable employees to discern their role in making the vision a reality (Ogbonnaya et al., 2015).

In addition to their signalling effects, HRM systems are relatively stable and can be institutionalized quite easily within an organization (Flood et al., 2008). That is to say, HRM systems have the potential of creating the type of culture needed to translate transformational leadership into long-term success for an organization (Ogbonnaya et al., 2015). We tie this perspective to Bowen and Ostroff's (2004: 205) argument that the set of practices adopted in HRM systems are often "driven by the strategic goals and values of the organization", which in turn, strengthen the cultural norms and behaviours within the organization. For example, if the strategic goal of an organization is to achieve financial performance, the set of HRM practices adopted would most likely reflect an orientation towards attaining financial success. The practices will be laid out in such a way as to encourage a shared basic understanding of what organizational actions, processes, and behaviours are necessary for achieving that goal. In a similar vein, we propose that the goals of transformational leadership (i.e., to inspire and elevate employees to higher levels of motivation) can be achieved through HPWP because the latter aim to support, motivate and develop a high-performing set of employees. HPWP can thus be utilized to foster and sustain a culture of perceived organizational support and 
innovation, so that the basic principles of transformational leadership become a lasting part of the organization's philosophy (Ogbonnaya et al., 2015).

\section{Mapping transformational leadership onto HPWP}

So far, we have discussed the interplay between transformational leadership and HPWP in line with the signalling effects of HRM practices, and have argued that HPWP provide a wide range of practices through which the transformational leader can send vital signals regarding what is expected of employees, and vice versa. One question that may arise, however, concerns the extent to which the fundamental principles of transformational leadership overlap with specific components of HPWP. For example, to what extent can a transformational leader's desire to foster employees' personal and professional development (i.e., individualized consideration) be realized through specific ability-enhancing practices in HPWP? Alternatively, to what extent do opportunity-enhancing practices such as information sharing and participative decision-making illustrate key aspects of inspirational motivation? In the following section, we try to map the four dimensions of transformational leadership (idealized influence, inspirational motivation, and intellectual stimulation) onto the ability-, motivation-, and opportunity-enhancing components of HPWP. In Table 2, we illustrate the overlap between transformational leadership and HPWP, and give examples of how specific HRM practices can be used to make transformational leadership more observable.

Insert Table 1 about here.

The transformational leader's idealized influence can be manifested through HRM practices that allow the leader to express his/her level of concern, thoughtfulness, and value for employees. Some of the HRM practices identified for this purpose are motivationenhancing practices such as supportive management, job security guarantees, and fairness in compensation pay, as well as ability-enhancing practices such as training and selective hiring 
(see Table 2, Row 2). Idealized influence involves leading by example, respecting and trusting employees, empathizing with them, and generally behaving in a manner that shows high levels of consideration for the welfare of those under one's supervisory or managerial authority (Bass, 1991; Barroso Castro et al., 2008). Although these qualities are endearing, they are not necessarily easy to live up to in reality. However, by ensuring fairness in compensation pay, training and recruitment activities, or by guaranteeing employees' job security, the transformational leader can at least begin to manifest his/her genuine value and consideration for employees. Supportive management is also essential for establishing a climate of empathy and cooperation within the workplace (Takeuchi et al., 2009; Whitener, 2001). It involves simple actions such as being friendly and helping employees in handling difficult tasks (Patterson, et al., 2004), or enacting family-friendly workplace policies on sickness absence and parental-care leave arrangements (Ngo, Foley \& Loi, 2009).

The transformational leader's role as an inspirational motivator involves articulating a compelling vision and communicating this vision in a way that inspires employees to become passionate about the vision (Bass \& Riggio, 2006). This role can be facilitated by the leader's ability to set positive but realistic goals, and communicate these goals in a manner that is understandable, precise and reflects a collective sense of purpose (Avolio \& Bass, 1995; Van Knippenberg \& Sitkin, 2013). As shown in Table 2 (Row 3), opportunity-enhancing practices such as information sharing and participative decision-making are relevant to this communication process. Information sharing, for example, involves disseminating vital organizational information to employees via consultative meetings, team briefings, monthly newsletters, message boards and so on. This type of activity increases employees' knowledge about the organization (or the leader's vision) and allows employees to align their interests more closely to organizational values (Paré \& Tremblay, 2007). In terms of participative decision-making activities, employees are encouraged to share or participate in the planning 
and formulation of workplace decisions (Ogbonnaya \& Valizade, 2015). Employees are enabled to have a 'say' in these decisions and express their opinions in determining the success of an organization. The participatory nature of these communication channels can allow the transformational leader to convey his/her plans in a way that is inspiring and inclusive of all employees, and at the same time, employees are able to feed their opinions back to the leader.

Another important characteristic of transformational leadership is to provide an enabling environment for innovation and creativity. Part of being a transformational leader involves intellectual stimulation, the leader's ability to challenge employees, encourage them to share new ideas, confront old problems in unconventional ways or adopt novel approaches to problem solving. The transformational leader can intellectually stimulate employees by designing their jobs in a way that encourages discretionary effort. For example, task autonomy, an opportunity-enhancing practice, enables employees to control their jobs and directly influence their day-to-day responsibilities (Appelbaum et al., 2000; Paré \& Tremblay, 2007). The transformational leader may emphasize task autonomy in the design of employees' jobs so that employees are empowered to apply their creative knowledge rather than being narrowly constrained in terms of what they are able do in their jobs (Kalmi \& Kauhanen, 2008). A transformational leader may also intellectually stimulate employees by encouraging them to work in teams (see Table 2 - Row 4, Column 4). When implemented properly, team-based working enables employees to utilize and maximize their work-related skills. Team working creates scope for mutual support, collective learning and knowledge sharing (Van Mierlo et al., 2001), all of which can be intellectually stimulating, and can improve employees' sense of work meaningfulness and well-being.

Individualized consideration concerns the extent to which the transformational leader is able to coach and mentor employees, attend to their individual needs, and encourage them 
to expand their personal, professional, and cognitive abilities (Nielsen et al., 2008). In Table 2 (Row 5, Column 2), we show that these characteristics may be operationalized through the provision of specialized employee training. Although employee training may take many different forms - such as on-the-job coaching and mentoring, off-the-job training, and skillenhancement workshops - the common feature among this range of training activities is that they reinforce employees' personal and professional development. Thus, a transformational leader may directly attend to employees' learning needs by coaching or mentoring them on the job, or indirectly by encouraging them to make the most of off-the-job training opportunities. Individualized consideration can also be manifested through routine appraisals of employees' learning and performance needs. Performance appraisal is a motivationenhancing practice aimed at assessing the performance of employees based on a set of predetermined criteria (Macky \& Boxall, 2007; Jiang et al., 2012). It is useful for identifying the training needs of employees and benchmarking their personal and professional development over a given time period.

Our mapping of key aspects of transformational leadership onto individual components of HPWP strengthens the idea that HRM practices can be used to make transformational leadership more observable in the workplace. However, we propose that the literature would benefit from a more thorough examination of the links between transformational leadership and individual components of HPWP, as well as a closer look at how both strategies can be applied together in contemporary workplaces. For instance, whilst we were able to map idealized influence onto six HRM practices (Table 2, Row 2), individualized consideration was mapped onto only three HRM practices (Table 2, Row 5). This suggests, at least from our point of view, that a transformational leader who wishes to be individually considerate may find a limited set of practices within the HPWP framework to achieve this. A natural progression from the present paper, therefore, is to examine more 
closely how different aspects of transformational leadership overlap with a broad spectrum of HRM practices, policies and routines. Research on this would not only extend our understanding of how transformational leadership can be manifested through HRM systems, but inform the debate as to what practices should be included in HPWP.

\section{Mutual gains for employees and the organization}

There is substantial evidence to show that transformational leadership has positive effects on both employee- and organizational-level outcomes (see meta-analysis: Judge \& Piccolo, 2004). In addition, a vast amount of HPWP studies have reported positive effects on both employee- and organizational-level outcomes (see systematic review: Van De Voorde et al., 2012). Based on these reviews, it seems safe to say that transformational leadership and HPWP can be used together to achieve mutual gains for both employees and the organization. In organizational research, 'mutual gains' connotes a 'win-win' situation in which two or more interdependent parties establish jointly shared benefits from an organizational phenomenon (Cullinane, Donaghey, Dunon, Hickland \& Dobbins, 2014). In the context of transformational leadership and HPWP, there are at least three main parties involved - the employees (or followers), the transformational leader, and the organization itself. Mutuality of benefits may therefore include improved employee psychological well-being (e.g., higher job satisfaction, reduced anxiety and lower depression), greater levels of employee commitment and dedication to the leader's vision, and superior organizational performance.

One of the ways in which transformational leadership and HPWP may jointly improve employee psychological well-being is by augmenting the repertoire of job resources available to employees (Ogbonnaya et al., 2015). Both transformational leadership and HPWP provide a wide range of job resources at the organizational level (e.g., job security) and individual level (e.g., job autonomy) that strengthen employees' resource reservoir for handling high work demands and potential causes of poor psychological well-being. Pertinent here is the 
Conservation of Resources (COR) theory, according to which individuals strive to secure, preserve, foster, and protect their resources in order to cope with stressful situations (Gorgievski \& Hobfoll, 2008; Hobfoll, 2001; Byrne et al., 2014). Resources in this context include personal characteristics (e.g., self-esteem and optimism), energies (e.g., pay and skills), or conditions (e.g., social support and job security) that prevent potential suffering and help to fulfil one's basic human needs (Hobfoll, 2001). According to COR theory, individuals are more likely to experience high stress levels when: (1) key resources are threatened with loss, (2) key resources are actually lost, or (3) when individuals fail to gain resources from significant resource investment. We interpret this to suggest that employees who have job resources made available to them through the combined use of transformational leadership and HPWP are able to replenish their resource reservoirs, and consequently experience lower levels of work-related stress.

We have argued in the present paper that HPWP may be utilized by a transformational leader to send strong signals regarding what attitudes and behaviours are expected from employees. But what happens after employees have received these signals? Are they likely to respond favourably, perhaps, if the signals are perceived as positive treatment from the transformational leader, or unfavourably, if the signals are perceived otherwise? To shed light on this perspective, we draw on 'norm of reciprocity', the tendency for employees to reciprocate either positively or negatively based on their interpretation of treatment received from their leader, manager or employer (Eisenberger et al., 1990). A well-established stream of research has shown that the signals communicated via coherent HRM systems are often interpreted positively by employees, and this obliges employees to reciprocate through greater levels of commitment to the organization (Eisenberger et al., 1990; Gould-Williams, 2003; Whitener, 2001; Gould-Williams, 2007). Thus, if a transformational leader's vision is applied in conjunction with a coherent HRM system (e.g. HPWP), we expect employees to 
respond through greater levels of commitment and dedication to the vision. The rationale is that both transformational leadership and HPWP work together to generate positive feelings of optimism, value, and meaningfulness among employees. These positive feelings, in turn, increase employees' willingness to exert their physical and cognitive energies in order to deliver on the transformational leader's vision.

With high levels of psychological well-being and employees' willingness to deliver on the transformational leader's vision, one could anticipate superior levels of organizational performance. Positive psychological well-being enhances the quality of employees' functioning at work, thereby energizing them to invest their time, effort and knowledge on behalf of the organization (Van De Voorde et al., 2012). This assumption is consistent with the notion that happy workers are also productive workers (Taris \& Schreurs, 2009; Wright \& Cropanzano, 2007). Happiness in this context is defined broadly to include employees' experience of job satisfaction, motivation, contentment and other aspects of psychological and cognitive well-being (Wright \& Cropanzano, 2007). When employees are exposed to conditions that improve their experience of happiness at work, they take pride in performing high-quality jobs to enhance the productive capacity of the organization. Happy employees also tend to be confident, passionate about their jobs, and motivated to exert organizational citizenship behaviours. If through the combined use of transformational leadership and HPWP employees are supported to elicit positive workplace behaviours, we can expect improved organizational performance.

\section{What if transformational leadership and HPWP are misapplied?}

Although we have illustrated how transformational leadership and HPWP can be used together for an effective organization, it is possible for the combined use of both models to be counterproductive if their key principles are misapplied (Ogbonnaya et al., 2015). For instance, HPWP may be misapplied if enacted primarily to drive organizational performance 
at the expense of employee well-being (Ramsay et al., 2000; Kroon, Van de Voorde \& Van Veldhoven, 2009). In such a situation, the employee might experience increased work intensification, and correspondingly, poor psychological health and well-being. The research in this area has featured under what has become known as the 'critical perspective' of HPWP (Kalmi \& Kauhanen, 2008). Researchers have also begun exploring a possible 'dark side' of transformational leadership (Hutchinson \& Jackson, 2013; Tourish, 2013). The key tenet of this emerging literature is that a transformational leader inherently intends to act constructively towards employees, but pressures of driving organizational performance may cause the leader to have high expectations of employees and inadvertently exhibit destructive behaviours. Drawing on these two emerging strands of literature, we explore some of the ways in which aligning transformational leadership with HPWP may be counterproductive.

Today's global business environment is increasingly characterized by shrinking budgets and stiff competition that place undue pressures on organizations. To survive in a harsh business environment, some leaders may adopt control mechanisms to channel employees' physical, intellectual and emotional energies towards achieving their vision at any cost (Tourish, 2013). The leader may, for example, rely on his/her reputation as a charismatic role model, or use effective communication channels (e.g., information sharing in HPWP) to indoctrinate employees and ensure their conformance to a new set of behaviours aimed at achieving the leader's vision. Conformity in this light represents what Tourish (2013: 41) described as coercive persuasion. Coercive persuasion or 'brainwashing' involves a dynamic process of indoctrination in which the victim's ability to act or think independently is subtly violated (Ventegodt, Andersen \& Merrick, 2009). The leader takes advantage of employees' confidence in his/her perceived 'good' organizational intentions, only to impose a vision that is, perhaps, a disguise of the leader's personal agenda (Ogbonnaya et al., 2015). Aligning HPWP with the leader's vision in such circumstances may reflect what critical 
authors have described as a managerial strategy designed to control employees in order to drive performance (Kroon et al., 2009; Ramsay et al., 2000).

Alternatively, the leader might resort to 'strategic bullying' rather than coercively persuade employees to conform to his/her vision. Strategic bullying (also tactical bullying) is a phenomenon in which a leader, so passionate about achieving his/her vision, resorts to maltreating employees through strategically selected tactics of influence (Conger, 1990; Ferris, Zinko, Brouer, Buckley \& Harvey, 2007). Such behaviours may include occasional emotional outbursts aimed at eliciting certain desired outcomes from employees, or influencing employees to act in some predetermined manner. It should be acknowledged that strategic bullying is rarely associated with genuine transformational leadership; however, such a behaviour may occur if the leader becomes unrealistic and sees the organization as a means for pursuing his/her personal agenda (Conger, 1990; Tourish, 2013). The leader may, for example, apply HPWP to maximize employees' skills and elicit discretionary effort from them, but to achieve his/her personal gains. The leader might induce employees to expend greater work effort, or compel them undertake too many job tasks, without paying much attention to the effects that his/her actions may have on the employee welfare. Adopting HPWP in this context may serve as a disguise for employee exploitation.

"Enacting high quality leadership requires the investment of considerable personal resources" (Byrne et al., 2014: 348). To be an effective transformational leader, for example, one needs to communicate an interesting vision, show optimism for future goals, appeal to employees' intellect, provide meaning for their work, and at the same time, attend to their individual and professional needs. These qualities are considerably difficult to express if a leader is in a state of resource depletion (Walter \& Bruch, 2007; Byrne et al., 2014). A transformational leader in a state of resource depletion is one that is low in resources such as self-confidence, emotional intelligence, and self-efficacy (Byrne et al., 2014). To illustrate, a 
transformational leader low in self-confidence may have difficulties playing his/her part as a role model, or may find it harder to elicit innovative thinking from employees. Similarly, a leader low in emotional intelligence may find it difficult to apply HPWP in a way that is empowering and not exploitative. Where a leader is depleted in terms of his/her psychological resources, he/she is also prone to displaying abusive leadership behaviours (Byrne et al., 2014). Abusive supervision concerns the extent to which a leader might engage in persistent displays of hostile verbal and nonverbal behaviours towards subordinates (Tepper, 2000).

\section{CONCLUSION}

Transformational leadership and HPWP have become mainstream topics in organizational research due to their positive effects on employee well-being and organizational performance outcomes. The present paper has illustrated the extent to which both strategies can be used together to promote an effective organization. HPWP serve as a medium through which employers send signals that enable employees to make sense of their work environment. These signals give employees a better understanding of what is expected of them and what the employer expects from them in return. The transformational leader can thus use HPWP to communicate his/her vision and plans to employees, ensuring that they are aware of their role in making the vision a reality. The present paper has also suggested that the way in which this message is transmitted to employees, and how it is interpreted, is crucial for improving employee well-being and developing an effective organization. Despite the benefits of applying transformational leadership in tandem with HPWP, there are also circumstances under which this approach may be misapplied. It is important for individual leaders and HRM practitioners to be aware of such circumstances and be wary of the potential adverse effects that they might have on employees and the organization. 


\section{REFERENCES}

Appelbaum, E., Bailey, T., Berg, P. \& Kalleberg, A. 2000. Manufacturing advantage: Why high-performance work systems pay off. Ithaca: ILR Press

Barling, J., Iverson, R. \& Kelloway, K. 2003. High-quality work, job satisfaction, and occupational injuries. Journal of Applied Psychology, 88: 276-283

Barroso Castro, C., Villegas Perinan, M. \& Casillas Bueno, J. 2008. Transformational leadership and followers' attitudes: the mediating role of psychological empowerment. The International Journal of Human Resource Management, 19: 1842-1863.

Beltrán-Martín, I., Roca-Puig, V., Escrig-Tena, A. \& Bou-Llusar, J. 2008. Human resource flexibility as a mediating variable between high performance work systems and performance. Journal of Management, 34: 1009-1044

Burns, J. 1978. Leadership. New York: Harper \& Row.

Byrne, A., Dionisi, A., Barling, J., Akers, A., Robertson, J., Lys, R., ... \& Dupré, K. 2014. The depleted leader: The influence of leaders' diminished psychological resources on leadership behaviors. The Leadership Quarterly, 25: 344-357.

Combs, J., Liu, Y., Hall, A. \& Ketchen, D. 2006. How much do high-performance work practices matter? A meta-analysis of their effects on organizational performance. Personnel Psychology, 59: 501-528

Conger, J. 1990. The dark side of leadership. Organizational Dynamics, 19: 44-55.

Cullinane. N., Donaghey, J., Dunon, T., Hickland, E. \& Dobbins, T. 2014. Regulating for mutual gains? Non-union employee representation and the Information and Consultation Directive. The International Journal of Human Resource Management, 25: 810-828.

Danna, K., \& Griffin, R. W. 1999. Health and well-being in the workplace: A review and synthesis of the literature. Journal of management, 25: 357-384. 
Delery, J. 1998. Issues of fit in strategic human resource management: Implications for research. Human Resource Management Review, 8: 289-309

Edwards, P. \& Wright, M. 2001. High-involvement work systems and performance outcomes: The strength of variable, contingent and context-bound relationships. The International Journal of Human Resource Management, 12: 568-585

Ferris, G., Zinko, R., Brouer, R., Buckley, M. \& Harvey, M. 2007. Strategic bullying as a supplementary, balanced perspective on destructive leadership. The Leadership Quarterly, 18: 195-206

Flood, P., Ramamoorthy, N., Mcdermott, A. \& Conway, E. 2008. Leadership, human resource management and the content of the psychological contract. The learning, innovation and knowledge (LINK) research centre working paper series

García-Morales, V., Jiménez-Barrionuevo, M. \& Gutiérrez-Gutiérrez, L. 2012. Transformational leadership influence on organizational performance through organizational learning and innovation. Journal of Business Research, 65: 1040-1050.

Gorgievski, M. \& Hobfoll, S. 2008. Work can burn us out or fire us up: Conservation of resources in burnout and engagement. In J.R.B. Halbesleben (Ed.), Handbook of stress and burnout in health care. New York: Nova Science Publishers.

Godard, J. 2001. High performance and the transformation of work? The implications of alternative work practices for the experience and outcomes of work. Industrial and Labor Relations Review, 54: 776-805

Gong, Y., Law, K., Chang, S. \& Xin, K. 2009. Human resources management and firm performance: The differential role of managerial affective and continuance commitment. Journal of Applied Psychology, 94: 263-275 
Gould-Williams, J. 2003. The importance of HR practices and workplace trust in achieving superior performance: a study of public-sector organizations. The International Journal of Human Resource Management, 14: 28-54

Hobfoll, S. 2001. The influence of culture, community, and the nested self in the stress process: Advancing conservation of resources theory. Applied Psychology: An International Review, 50: 337-370.

Huselid, M. 1995. The impact of human resource management practices on turnover, productivity, and corporate financial performance. Academy of Management Journal, 38: $635-872$

Hutchinson, M. \& Jackson, D. 2013. Transformational leadership in nursing: Towards a more critical interpretation. Nursing inquiry, 20: 11-22

Ichniowski, C., Shaw, K. \& Prennushi, G. 1997. The effects of human resource management practices on productivity: A study of steel finishing lines. The American Economic Review, 87: 291-313

Jiang, K., Lepak, D. \& Baer, J. 2012. How does human resource management influence organizational outcomes? A meta-analytic investigation of mediating mechanisms. Academy of Management Journal, 55: 1264-1294.

Jiang, J. \& Liu, C. 2015. High performance work systems and organizational effectiveness: the mediating role of social capital. Human Resource Management Review, 25: 126137

Judge, T. \& Piccolo, R. 2004. Transformational and transactional leadership: a meta-analytic test of their relative validity. Journal of applied psychology, 89: 755-768

Kalmi, P. \& Kauhanen, A. 2008. Workplace innovations and employee outcomes: Evidence from Finland. Industrial Relations: A Journal of Economy and Society, 35: 430-459 
Kroon, B., Van de Voorde, K. \& Van Veldhoven, M. 2009. Cross-level effects of highperformance work practices on burnout: Two counteracting mediating mechanisms compared. Personnel Review, 38: 509-525

Lengnick-Hall, M. L., Lengnick-Hall, C. A., Andrade, L. S. \& Drake, B. 2009. Strategic human resource management: The evolution of the field. Human Resource Management Review, 19: 64-85.

Loshali, S. \& Krishnan, V. 2013. Strategic human resource management and firm performance: Mediating role of transformational leadership. Journal of Strategic Human Resource Management, 2: 9-19

MacDuffie, J. 1995. Human resource bundles and manufacturing performance: Organizational logic and flexible production systems in the world auto industry. Industrial and Labor Relations Review, 48: 197-221

Macky, K. \& Boxall, P. 2008. High-performance work systems and employee well-being: Does employee involvement really intensify work? Asia Pacific Journal of Human Resources, 46: 38-55

Nielsen, K., Randall, R., Yarker, J. \& Brenner, S. 2008. The effects of transformational leadership on followers' perceived work characteristics and psychological well-being: A longitudinal study. Work \& Stress, 22: 16-32.

Ngo, H., Foley, S. \& Loi, R. 2009. Family friendly work practices, organizational climate, and firm performance: A study of multinational corporations in Hong Kong. Journal of Organizational Behavior, 30: 665-680

Ogbonnaya, C. \& Valizade, D. 2015 Participatory workplace activities, employee-level outcomes and the mediating role of work intensification. Management Research Review 38: 540-558. 
Ogbonnaya, C., Daniels, K., Connolly, S., van Veldhoven, M. \& Nielsen, K. (In press). Employees, managers and high performance work practices: A 'win-win' or the transformational leader's exploitative approach to organizational performance. In: N. M. Ashkanasy, R. J. Bennett \& M. J. Martinko, (Eds) Understanding the high performance workplace: The line between motivation and abuse. New York: Routledge

Paré, G. \& Tremblay, M. 2007. The influence of high-involvement human resources practices, procedural justice, organizational commitment, and citizenship behaviours on information technology professionals' turnover intentions. Group \& Organization Management, 32: 326-357

Pereira, C. \& Gomes, J. 2012. The strength of human resource practices and transformational leadership: impact on organisational performance. The International Journal of Human Resource Management, 23: 4301-4318.

Piccolo, R. \& Colquitt, J. 2006. Transformational leadership and job behaviors: The mediating role of core job characteristics. Academy of Management Journal, 49: 327340.

Purcell, J. \& Hutchinson, S. 2007. Front-line managers as agents in the HRM-performance causal chain: Theory, analysis and evidence. Human Resource Management Journal, 17: 3-20.

Ramsay, H., Scholarios, D. \& Harley, A. 2000. Employees and high-performance work systems: Testing inside the black box. British Journal of Industrial Relations, 38: 501-531

Skakon, J., Nielsen, K., Borg, V. \& Guzman, J. 2010. Are leaders' well-being, behaviours and style associated with the affective well-being of their employees? A systematic review of three decades of research. Work \& Stress, 24: 107-139. 
Sun, L., Aryee, S. \& Law, K. 2007. High-performance human resource practices, citizenship behavior, and organizational performance: A relational perspective. Academy of Management Journal, 50: 558-577

Taris, T. \& Schreurs, P. 2009. Well-being and organizational performance: An organizational-level test of the happy-productive worker hypothesis. Work \& Stress, 23: $120-136$.

Tims, M., Bakker, A. \& Xanthopoulou, D. 2011. Do transformational leaders enhance their followers' daily work engagement? The Leadership Quarterly, 22: 121-131

Tourish, D. 2013. The dark side of transformational leadership: A critical perspective. East Sussex: Routledge

Van De Voorde, K., Paauwe, J. \& Van Veldhoven, M. 2012. Employee well-being and the HRM-organizational performance relationship: A review of quantitative studies. International Journal of Management Reviews, 14: 391-407.

Van Knippenberg, D. \& Sitkin, S. 2013. A critical assessment of charismatictransformational leadership research: Back to the drawing board? Academy of Management Annals, 7: 1-60.

Ventegodt, S., Andersen, N. \& Merrick, K. 2009. An ethical analysis of contemporary use of coercive persuasion ("brainwashing","mind control") in psychiatry. Journal of Alternative Medicine Research, 1: 177-188.

Walter, F. \& Bruch, H. 2007. Investigating the emotional basis of charismatic leadership: The role of leaders' positive mood and emotional intelligence. In C. E. J. Härtel, N. M. Ashkanasy, \& W. J. Zerbe (Eds.), Research on emotion in organizations, p. 55-85, Amsterdam: Elsevier 
White, M., Hill, S., McGovern, P., Mills, C. \& Smeaton, D. 2003. High-performance management practices, working hours and work-life balance. British Journal of Industrial Relations, 41: 175-195

Whitener, E. 2001. Do "high commitment" human resource practices affect employee commitment? A cross-level analysis using hierarchical linear modelling. Journal of Management, 27: 515-535

Wood, S. 1999. Human resource management and performance. International Journal of Management Reviews, 1: 367-413

Wood, S. \& De Menezes, L. 2011. High involvement management, high-performance work systems and well-being. The International Journal of Human Resource Management, 22: 1584-1608

Wood, S., Van Veldhoven, M., Croon, M. \& De Menezes, L. 2012. Enriched job design, high involvement management and organizational performance: The mediating roles of job satisfaction and well-being. Human Relations, 65: 419-4

Wright, T. \& Cropanzano, R. 2007. The happy/productive worker thesis revisited. Research in Personnel and Human Resources Management, 26: 269-307.

Zhu, W., Chew, I., \& Spangler, W. 2005. CEO transformational leadership and organizational outcomes: The mediating role of human-capital-enhancing human resource management. The Leadership Quarterly, 16: 39-52. 
TABLE 1

Components of HPWP

\section{HRM Practices}

\section{Ability-enhancing practices}

Selective hiring

Induction activities

Staff training

\section{Motivation-enhancing practices}

Supportive management

Job security guarantees (e.g., in employment terms and conditions)

Performance appraisal

Career opportunities

Compensation pay

Grievance procedures

\section{Description}

Rigorous recruitment procedures used to select new employees

Formal training offered to enhance employees' knowledge about the job, and teach them relevant skills pertaining to their job role

Training offered by the employer to enhance specific employee skills and expertise

Level of care and support offered to help employees perform their jobs more effectively

Employees are assured of the stability of their employment

Assessing employees' job performance periodically based on a set of organizational criteria

Employees have opportunities (e.g., through promotion) to progress in their job and career

Employees are offered equitable payments such as profitsharing or pay for performance,

Workplace has standard procedures for airing and resolving complaints and grievances
Huselid, 1995; Ichniowski et al., 1997; Whitener, 2001; BeltránMartín et al., 2008; Gong et al., 2009; Jiang et al., 2012

MacDuffie, 1995; Huselid, 1995; Ramsay et al., 2000; Sun et al., 2007; Takeuchi et al., 2009

Ichniowski et al., 1997; Gould-Williams, 2003; Barling et al., 2003; Macky \& Boxall, 2007; Gong et al., 2009; Kalmi \& Kauhanen, 2008

Ramsay et al., 2000; Whitener, 2001; Gould-Williams and Davies, 2005; Wood and De Menezes, 2011

Ichniowski et al., 1997; Combs et al., 2006; Sun et al., 2007; Gong et al., 2009; Jiang et al., 2012

White et al., 2003; Beltrán-Martín et al., 2008; Gong et al., 2009; Wood and De Menezes, 2011; Wood et al., 2012

Huselid, 1995; Gould-Williams, 2003; Macky \& Boxall, 2007; Kroon et al., 2009; Jiang et al., 2012

Whitener, 2001; Gould-Williams, 2003; Macky \& Boxall, 2007; Gong et al., 2009; Takeuchi et al., 2009; Wood et al., 2012

Huselid, 1995; Ramsay et al., 2000; Takeuchi et al., 2009; Wood and De Menezes, 2011; Combs et al., 2006 
Employee representation

\section{Opportunity-enhancing practices}

Task autonomy

Task clarity and variety

Flexible work

Team working

Participative decision-making

Information sharing
Formal structures for representing and promoting the interests of employees

Employees' have direct influence over how to carry out their job tasks and responsibilities

Employees have clearly defined job tasks with meaningful levels of variety on the job

Employees can decide where and when to undertake their job tasks (e.g., through job-sharing, flexi-time or job rotation arrangements)

Employees' work closely with each other in formally designated problem-solving work groups

Employees are allowed to contribute to workplace decisionmaking activities

Employees are kept updated with vital information regarding the job and workplace
Ichniowski et al, 1997; Ramsay et al., 2000; Edwards and Wright, 2001; Wood and De Menezes, 2011

Ramsay et al., 2000; Barling et al., 2003; Wood and De Menezes, 2011; Wood et al., 2012

MacDuffie, 1995; Gould-Williams, 2003; Sun et al., 2007; Kroon et al., 2009; Jiang et al., 2012; Wood et al., 2012

Ichniowski et al, 1997; MacDuffie, 1995; Ramsay et al., 2000; Combs et al., 2006

MacDuffie, 1995; Ramsay et al., 2000; Gould-Williams, 2003; Macky \& Boxall, 2007; Takeuchi et al., Combs et al., 2006

Ichniowski et al, 1997; Gould-Williams, 2003; Sun et al., 2007; Gong et al., 2009, Ogbonnaya and Valizade, 2015

Huselid, 1995; Gould-Williams, 2003; Takeuchi et al., 2009; Wood et al., 2012; Ogbonnaya and Valizade, 2015 
TABLE 2

Mapping transformational leadership onto HPWP

\begin{tabular}{|c|c|c|c|}
\hline & Ability-enhancing practices & Motivation-enhancing practices & Opportunity-enhancing practices \\
\hline $\begin{array}{l}\text { Idealized } \\
\text { influence }\end{array}$ & $\begin{array}{l}\text { Training - leader ensures fairness in } \\
\text { training provisions. All employees are } \\
\text { offered training opportunities irrespective } \\
\text { of their employment status } \\
\text { Selective hiring - leader avoids favouritism } \\
\text { and recruitment bias when filling job } \\
\text { vacancies }\end{array}$ & $\begin{array}{l}\text { Supportive management - leader helps employees to } \\
\text { perform their jobs more effectively } \\
\text { Job security guarantees - leader demonstrates adequate } \\
\text { concern for employees' employment status and conditions } \\
\text { Compensation pay - leader ensures fairness in distributing } \\
\text { pay incentives. The leader also ensures that pay is provided } \\
\text { in a timely manner to deserving employees }\end{array}$ & $\begin{array}{l}\text { Flexible work - by allowing flexible work } \\
\text { options the leader demonstrates his/her } \\
\text { concern for employees' work-nonwork } \\
\text { responsibilities }\end{array}$ \\
\hline $\begin{array}{c}\text { Inspirational } \\
\text { motivation }\end{array}$ & $\begin{array}{l}\text { Induction activities - employees are } \\
\text { informed about the leader's vision during } \\
\text { induction programs, and are made aware of } \\
\text { the skills set needed to achieve the vision. }\end{array}$ & $\begin{array}{l}\text { Performance appraisal - leader ensures that the criteria for } \\
\text { assessing employee performance are in line with his/her } \\
\text { vision }\end{array}$ & $\begin{array}{l}\text { Information sharing - can be used to } \\
\text { disseminate information about the leader's } \\
\text { vision and plans } \\
\text { Participative decision-making - leader allows } \\
\text { employees to express their views in planning } \\
\text { and formulating strategies for implementing } \\
\text { the leader's vision }\end{array}$ \\
\hline $\begin{array}{l}\text { Intellectual } \\
\text { stimulation }\end{array}$ & $\begin{array}{l}\text { Selective hiring - leader recruits qualified } \\
\text { individuals who are creative and willing to } \\
\text { forgo their personal interests on behalf of } \\
\text { the organization }\end{array}$ & $\begin{array}{l}\text { Career opportunities - leader sets employee promotion } \\
\text { criteria that encourage creativity and innovative thinking } \\
\text { Compensation pay - leader provides performance-related } \\
\text { pay to encourage employees to show initiative at work }\end{array}$ & $\begin{array}{l}\text { Task autonomy - employees are allowed to } \\
\text { directly influence the nature of their jobs and } \\
\text { discover ways to work smarter } \\
\text { Team working - encourages mutual support, } \\
\text { collective learning and knowledge sharing }\end{array}$ \\
\hline $\begin{array}{l}\text { Individualized } \\
\text { consideration }\end{array}$ & $\begin{array}{l}\text { Training - leader offers specialized training } \\
\text { to meet employees' learning, personal and } \\
\text { professional needs }\end{array}$ & $\begin{array}{l}\text { Performance appraisal - criteria for assessing employees' } \\
\text { job performance identify areas of employees' personal and } \\
\text { professional development }\end{array}$ & $\begin{array}{l}\text { Task autonomy - leader gives employees a } \\
\text { greater sense of responsibility for their job, } \\
\text { thus allowing them to self-actualize }\end{array}$ \\
\hline
\end{tabular}

